\title{
Base científica para a erradicação de plantas sintomáticas e assintomáticas de Huanglongbing (HLB, Greening) visando o controle efetivo da doença
}

\author{
José Belasque Junior ${ }^{1}$, Armando Bergamin Filho ${ }^{2}$, Renato Beozzo Bassanezi ${ }^{1}$, José Carlos Barbosa ${ }^{3}$, Nelson \\ Gimenes Fernandes ${ }^{1}$, Pedro Takao Yamamoto ${ }^{1}$, Silvio Aparecido Lopes ${ }^{1}$, Marcos Antônio Machado ${ }^{4}$, Rui \\ Pereira Leite Junior ${ }^{5}$, Antônio Juliano Ayres ${ }^{1}$ \& Cícero Augusto Massari ${ }^{1}$
}

${ }^{1}$ Fundo de Defesa da Citricultura-Fundecitrus, 14801-970, Araraquara, SP, Brasil; ${ }^{2}$ Departamento de Entomologia, Fitopatologia e Zoologia Agrícola, ESALQ, Universidade de São Paulo, 13418-900, Piracicaba, SP, Brasil; ${ }^{3}$ Departamento de Ciências Exatas, Faculdade de Ciências Agrárias e Veterinárias, Universidade Estadual Paulista, 14870-000, Jaboticabal, SP, Brasil; ${ }^{4}$ Centro APTA Citros "Sylvio Moreira", Instituto Agronômico de Campinas, 13490-970, Cordeirópolis, SP, Brasil; ${ }_{5}^{5}$ Instituto Agronômico do Paraná - IAPAR, 86001-970, Londrina, PR, Brasil

Autor para correspondência: José Belasque Junior, e-mail: belasque@fundecitrus.com.br

\section{Introdução}

Huanglongbing (HLB), ou Greening, é a doença mais importante e destrutiva da citricultura mundial (Bové, 2006; Gottwald et al., 2007a). Presente de forma endêmica nos continentes asiático e africano há várias décadas, essa doença foi recentemente detectada nos dois principais países produtores de citros, Brasil e Estados Unidos (Colleta Filho et al., 2004; Halbert, 2005; Teixeira et al., 2005). O Brasil detém $30 \%$ da produção mundial de laranja e $59 \%$ da produção de suco de laranja (Neves et al., 2007). São Paulo e Flórida dominam a oferta mundial, um caso raro em se tratando de commodities agrícolas. O sistema agroindustrial citrícola brasileiro movimenta anualmente $\mathrm{R} \$ 9$ bilhões e gera mais de 400 mil empregos diretos e indiretos. Pelos danos que causa e pela dificuldade do seu manejo, o HLB coloca em risco esse importante setor do agronegócio brasileiro. Há necessidade de ações conjuntas urgentes envolvendo citricultores, indústrias processadoras e os governos federal e estaduais. Em 17 de Outubro de 2008 entrou em vigor a Instrução Normativa $n^{\circ} 53$, a qual altera as normas concernentes à erradicação do HLB no Brasil. No presente trabalho, por meio da compilação de dados experimentais, alguns recentes e ainda não publicados, justifica-se a necessidade de ações efetivas de controle dessa doença e descreve-se a nova metodologia para a erradicação de plantas cítricas sintomáticas e assintomáticas presentes em áreas infestadas pela doença.

\section{Histórico e distribuição do HLB no Brasil}

Os primeiros sintomas de HLB foram observados em Março de 2004, em plantas de pomares localizados na região de Araraquara, Estado de São Paulo (Colletta Filho et al., 2004; Teixeira et al., 2005). Essa foi a primeira detecção da doença no continente americano. Em 2005 ocorreu a primeira detecção da doença em Minas Gerais e em 2007 no Paraná. Ao menos 46 municípios registravam ao menos um pomar citrícola afetado com HLB, em Setembro de 2004, no Estado de São Paulo. Poucos desses pomares, todos presentes na região de Araraquara, tinham mais que $50 \%$ de plantas sintomáticas. Em Outubro desse mesmo ano foi realizado o primeiro levantamento amostral da doença em São Paulo. Foram detectados 3,4\% de talhões com a presença de HLB, todos nas regiões Centro e Sul do Estado. Na época, essas duas regiões apresentaram, em média, 8,6 e 2,0\% de talhões infestados, respectivamente. O município de maior incidência foi Araraquara, com $20,3 \%$ de pomares com ao menos uma planta sintomática. No segundo levantamento amostral, realizado em Setembro de 2007, foram encontrados $12,9 \%$ de talhões infestados em todo o estado. Além das regiões Centro e Sul, com 19,3 e $18,2 \%$ de talhões infestados, respectivamente, a doença foi detectada na região Norte de São Paulo, em $1 \%$ dos pomares. Um terceiro levantamento amostral foi realizado em Abril de 2008, porém, além da estimativa de talhões infestados, estimou-se o número de plantas com sintomas de HLB. Constatou-se que em São Paulo a doença continuou a aumentar de forma acelerada e ocorria em todas as regiões citrícolas do Estado. A porcentagem de pomares infestados aumentou para $18,6 \%$ e constatouse $0,58 \%$ de plantas sintomáticas (aproximadamente 1,15 milhão de plantas). O último levantamento foi realizado em Abril de 2009. Da mesma forma como observado nos anos anteriores, novas regiões, pomares e plantas afetadas pela doença foram constatadas. Nesse levantamento, foram detectados 24\% dos pomares do Estado de São Paulo com 
ao menos uma planta sintomática e $0,9 \%$ de plantas doentes (aproximadamente 1,9 milhão de plantas) (Tabela 1).

Nos dois últimos levantamentos (2008 e 2009), a procura por plantas sintomáticas foi feita por inspetores a pé, caminhando pelo chão, em $10 \%$ das linhas de cada pomar (talhão) sorteado no levantamento. Bassanezi et al. (2006b) demonstraram que em uma inspeção a pé, feita em 12,5\% das linhas de cada talhão, a doença é detectada em mais de $89 \%$ dos talhões com incidência acima de $1 \%$, mas em apenas $56 \%$ dos talhões com incidência entre $0,5 \mathrm{e}$ $1 \%$, e em $46 \%$ dos talhões com incidência entre 0,1 e $0,5 \%$. Assim, pode-se afirmar que se subestimou a incidência do HLB, uma vez que, com a metodologia empregada, a doença não é detectada em todos os pomares com baixas incidências. Adicionalmente, em inspeções realizadas com inspetores caminhando pelo chão, detecta-se, em média, somente $47 \%$ das plantas sintomáticas (Belasque Jr. \& Barbosa, dados não publicados). Assim, pode-se afirmar que mais de 2 milhões de árvores apresentavam sintomas de HLB já em Abril de 2008 no Estado de São Paulo.

\section{Etiologia, sintomas e danos provocados pelo HLB}

Embora ainda não confirmado, considera-se que mais de uma espécie de bactéria pode ser o agente causal da doença, todas incitando, aparentemente, os mesmos sintomas em plantas cítricas. Essas bactérias são pertencentes a três espécies de procariotos Gram negativos, de colonização restrita ao floema das plantas, denominados Candidatus Liberibacter, pertencentes à subdivisão $\alpha$ de Proteobacteria, e transmitidos naturalmente por insetos vetores (psilídeos) - Diaphorina citri e Trioza erytreae (Bové, 2006). Em razão de essas bactérias ainda não terem sido cultivadas em meio de cultura artificial, têm-se a designação de Candidatus. Em função dos continentes em que foram primeiramente detectadas, as três espécies são denominadas Candidatus Liberibacter asiaticus, $\mathrm{Ca}$. Liberibacter africanus e $\mathrm{Ca}$. Liberibacter americanus (Jagoueix et al., 1994; Garnier et al., 2000; Teixeira et al., 2005). O tipo asiático está presente, além da Ásia, no Brasil, na Flórida e em Cuba (Martínez et al., 2009). O tipo americano foi detectado, até o momento, somente no Brasil. Praticamente todas as espécies e variedades comerciais de cítricos são suscetíveis à doença (Bové, 2006). Os tipos asiático e americano de $C a$. Liberibacter são transmitidos naturalmente por $D$. citri, enquanto o tipo africano possui como vetor T. erytreae. Em condições experimentais, ambos os vetores podem transmitir os tipos asiático e africano, mas há diferenças quanto à sensibilidade à temperatura ( $T$. erytreae e $\mathrm{Ca}$. Liberibacter africanus são sensíveis a temperaturas superiores a $25^{\circ} \mathrm{C}$ ) e quanto à distribuição geográfica do inseto (T. erytreae foi encontrada somente no continente africano e Oriente Médio) (Bové, 2006). Não há comprovação científica quanto à ocorrência de transmissão transovariana de Liberibacter em D. citri. Uma vez adquirida a bactéria, a transmissão ocorre por toda a vida do inseto (Bové, 2006). A planta conhecida como murta ou falsa-murta (Murraya paniculata), utilizada largamente como espécie ornamental no Brasil, também é hospedeira dos tipos asiático e americano de $\mathrm{Ca}$. Liberibacter e do inseto vetor $D$. citri.

Plantas com HLB apresentam, geralmente, pelo menos um dos sintomas descritos a seguir. O início do aparecimento dos sintomas é caracterizado pela presença de um ou poucos ramos com folhas amareladas, geralmente em poucas plantas no pomar. Huanglongbing, o nome oficial da doença, significa, em chinês, "doença do ramo amarelo". As folhas presentes nesses ramos perdem parte da sua coloração verde, apresentando-se parcialmente amarelas e verdes, sem uma delimitação clara entre essas duas cores. Esse tipo de sintoma é denominado "mosqueado". Esse é o sintoma mais característico de plantas com HLB, tendo sido observado em todos os locais nos quais a doença foi descrita até hoje, independentemente do agente causal, do hospedeiro e da condição ambiental (Bové, 2006). Há também uma assimetria dessas regiões verdes e amarelas, comparando-se os lados opostos do limbo foliar, delimitados pela nervura central. As folhas de ramos sintomáticos podem apresentar-se curvadas, de tamanho reduzido, com nervuras mais grossas e escurecidas. Em estádios mais avançados da doença podem ocorrer desfolha e morte de ponteiros. Frutos de ramos sintomáticos podem apresentar-se de tamanho reduzido, assimétricos, incompletamente maduros e com a região estilar mantendo-se verde, diferentemente de frutos de ramos sadios. Cortes perpendiculares ao eixo desses frutos permitem a observação de assimetria dos mesmos e também de sementes abortadas e vasos alaranjados.

TABELA 1 - Dados do levantamento amostral de Huanglongbing (HLB) realizado em Abril de 2009 no Estado de São Paulo

\begin{tabular}{lcccc}
\hline \hline Região & Número de pomares & Número de árvores & Pomares com HLB (\%) & Plantas com HLB (\%) \\
\hline Centro & 33.100 & 71.161 .424 & 33,1 & 1,35 \\
Norte & 19.801 & 45.184 .964 & 3,7 & 0,03 \\
Noroeste & 12.296 & 18.950 .278 & 0,1 & $<0,01$ \\
Oeste & 3.065 & 8.248 .289 & 10,0 & 0,06 \\
Sul & 27.861 & 70.649 .853 & 36,0 & 1,23 \\
\hline Total & 96.683 & 214.194 .808 & 24,0 & 0,87 \\
\hline
\end{tabular}


A queda de frutos sintomáticos é comumente observada em plantas doentes. Com o progresso dos sintomas aumenta a proporção de frutos sintomáticos e caídos. A redução na produção de frutos pode ser de até $100 \%$, dependendo da proporção da copa afetada (Bassanezi et al., 2006a). O HLB não provoca a morte das plantas, as quais, com o passar dos anos, ficam debilitadas e improdutivas. Observações de pomares afetados em diferentes regiões citrícolas do mundo, inclusive em São Paulo, revelam que pomares inteiros podem tornar-se inviáveis economicamente entre sete e dez anos após o aparecimento da primeira planta sintomática, se medidas de controle não são adotadas. Esse tempo pode ser menor para pomares jovens, de até quatro anos, os quais se tornam economicamente inviáveis em até cinco anos (Gottwald et al., 2007a). Além da queda precoce, frutos sintomáticos são menores e apresentam-se mais ácidos e com menores valores de Brix, ratio, porcentagem de suco e sólidos solúveis, reduzindo a qualidade do suco (Bassanezi et al., 2006a).

\section{Epidemiologia do HLB}

O período de incubação do HLB, ou seja, o período de tempo entre a infecção e o aparecimento dos sintomas da doença, depende de vários fatores como o ambiente (principalmente temperatura), a idade e espécie ou variedade da planta hospedeira, da concentração bacteriana na transmissão, da espécie de $C a$. Liberibacter, da época do ano, entre outros. Por essa razão, o período de incubação para HLB varia, geralmente, de seis a doze meses (Bové, 2006). Diante disso, além dos escapes que geralmente ocorrem nas inspeções realizadas para detecção de plantas sintomáticas, há outras plantas infectadas que permanecem no pomar, porém ainda assintomáticas.

Pomares altamente infestados, mantidos sem controle da doença, são fontes de inóculo para a infecção de pomares vizinhos em razão da migração de adultos de $D$. citri infectivos. Em pomares com aproximadamente $50 \%$ de plantas sintomáticas, a proporção de psilídeos infectivos foi a mesma para adultos coletados em plantas sintomáticas e em plantas assintomáticas (Bové, 2006). O autor explica essas proporções similares como resultante da movimentação dos insetos entre ramos e plantas do pomar. Dados preliminares de coletas de adultos de $D$. citri, realizadas em pomares infestados em São Paulo, revelaram porcentagens superiores a $60 \%$ de insetos infectivos quando originários de populações presentes em pomares com mais que $10 \%$ de plantas sintomáticas (Yamamoto et al., dados não publicados). Porcentagens similares de adultos infectivos foram observadas em diferentes locais na Flórida, mesmo quando em períodos de baixas populações do inseto (Manjunath et al., 2008). No entanto, o exemplo mais claro da presença de insetos infectivos, originários de áreas sem controle da doença foi apresentado por Tersi (2008). Coletas de adultos de D. citri realizadas em áreas com e sem a eliminação de plantas sintomáticas apresentaram médias de zero e $20,7 \%$ de insetos infectivos, respectivamente.
Vários são os aspectos que permanecem desconhecidos quanto à ecologia de $D$. citri, mas estudos sobre a distribuição espacial de plantas com sintomas de HLB em diversos países, incluindo o Brasil, sugerem a existência de dois mecanismos de dispersão do psilídeo gerando novos focos de infecção: i. a curta distância, geralmente de uma planta para a mais próxima como também para plantas distantes a 25-50 m (Gottwald et al., 1989; Gottwald et al., 1991; Bassanezi et al., 2005); ii. a longa distância, até $3,5 \mathrm{~km}$, com a distância mais comum entre 880 e $1610 \mathrm{~m}$ (Gottwald et al., 2007b). O primeiro mecanismo é responsável pela infecção secundária dentro do próprio talhão e o segundo pela infecção primária resultante de psilídeos infectivos, que periodicamente emigram de fontes de HLB externas aos talhões. Assim, propriedades distantes de plantas e pomares infestados podem obter melhores resultados de controle do HLB que propriedades em áreas próximas a outras com alta incidência. Mesmo que se faça a eliminação periódica de plantas sintomáticas em parte dos pomares e propriedades, juntamente com o controle do vetor, podem ocorrer migrações de insetos infectivos dos pomares sem controle da doença, o que resulta em novas infecções primárias na área sob controle. As medidas de controle devem ser adotadas em conjunto e todas as propriedades de uma região devem ser tratadas como sendo uma única unidade.

\section{Amostragem e detecção do HLB}

Como discutido por Bové (2006) e Gottwald et al. (2007a), o conhecimento da proporção de plantas sintomáticas e assintomáticas é importante e deve ser utilizado na decisão da eliminação de pomares inteiros altamente infestados. Segundo Bové (2006), quando da presença de muitas plantas sintomáticas, a melhor decisão de controle é a eliminação de todas as plantas do pomar, com e sem sintomas. O mesmo raciocínio foi desenvolvido por Gottwald et al. (2007a). O emprego simultâneo de dezenas de equipes de inspetores resultaria na detecção de todas, ou quase todas, plantas sintomáticas, mas ainda restariam as plantas infectadas assintomáticas para serem detectadas.

Ainda não há uma metodologia disponível que permita a detecção de todas as plantas infectadas com HLB, mesmo com o emprego de técnicas de diagnóstico mais modernas e sensíveis, como o PCR quantitativo em tempo real. Irey et al. (2006) compararam a deteç̧ão visual de plantas sintomáticas com a detecção por PCR (tempo real) de plantas infectadas. Em cinco blocos, de aproximadamente 190 plantas cada, foram detectadas aproximadamente 53 plantas com sintomas de HLB (observação visual) e PCR positivas para a presença da bactéria. Outras 39 plantas não apresentavam sintomas da doença, mas foram detectadas como PCR positivas, em amostras coletadas aleatoriamente na copa das plantas. Considerando todas as plantas infectadas detectadas por PCR $(53+39=92)$ como $100 \%$, na observação visual detectaram-se apenas $57,6 \%$ 
das plantas infectadas, existindo outras $42,4 \%$ de plantas infectadas ainda assintomáticas. Como discutido pelos próprios autores e também por Gottwald et al. (2007a), por uma questão de amostragem, somente parte das plantas infectadas assintomáticas é detectada por PCR. Essa técnica é altamente sensível e específica para detecção dos agentes causais do HLB, mas em coletas aleatórias de folhas, como feita para as plantas assintomáticas, nem sempre se coletam folhas com o patógeno. Isto se deve ao fato de o patógeno se distribuir irregularmente no interior das plantas infectadas. Apesar da sua detecção por testes moleculares ser possível em vários tipos de tecidos, como raízes, folhas (limbo foliar e nervuras), ramos, estruturas reprodutivas (pétalas, pistilos e estames) e de frutificação (pedúnculo, columela, endosperma e casca de sementes), mais comumente os resultados são PCR positivo para amostras de partes de plantas com sintomas típicos de HLB (Tatineni et al., 2008).

\section{Controle do HLB}

Não há medidas de controle efetivas e de baixo custo, nem mesmo métodos curativos, para o HLB. Desta forma, prevenir a infecção das plantas é fundamental no controle da doença. Foram realizadas tentativas de controle com a injeção de antibióticos (tetraciclinas), sem resultados promissores. Além do risco ambiental, uma vez interrompido o tratamento com antibiótico os sintomas reapareceram, ou seja, as plantas continuavam doentes (Bové, 2006). A poda de ramos sintomáticos e assintomáticos também foi testada como uma medida de controle da doença, porém foi prática ineficaz (Lopes et al., 2007). Atualmente, o controle preconizado envolve o plantio de mudas sadias, a eliminação de plantas doentes e o controle do inseto vetor. Portanto, o controle do HLB baseia-se na redução do inóculo, presente em plantas e insetos vetores. Medidas adicionais também devem ser empregadas, quando possível, como a eliminação das plantas de murta (M. paniculata), independentemente de sua localização. Essas medidas requerem tempo, recursos humanos e financeiros, e também a coordenação dos vários agentes envolvidos na produção de cítricos (produtores, governo e indústrias processadoras).

$\mathrm{Na}$ Figura 1 são apresentados exemplos de porcentagens acumuladas de plantas erradicadas com HLB em três propriedades comerciais localizadas na região central do Estado de São Paulo. Nestas propriedades foram realizadas inspeções periódicas (a cada 1 a 4 meses) para detecção e eliminação imediata de plantas sintomáticas, e também realizadas aplicações de inseticidas para o controle de D. citri. Observa-se o aumento gradual do número de plantas erradicadas, tendo variado o número de plantas eliminadas de acordo com a propriedade e época das inspeções. A perda anual de plantas foi de no máximo $2 \%$ após o início do controle, ocorrida na propriedade A (Figura 1). Esses dados permitem concluir que o controle e supressão do HLB, embora trabalhoso e custoso, é possível.
Uma erradicação anual de $2 \%$ de plantas permitiria que pomares sob controle do HLB se mantivessem produtivos e economicamente viáveis. Por outro lado, a manutenção de plantas doentes nos pomares os torna inviáveis economicamente em menos de dez anos após a constatação da primeira planta com sintomas do HLB (Roistacher, 1996).

O controle químico do vetor é a medida de controle mais facilmente adotada pelo citricultor. Apesar de amplamente adotada, poucas são as informações a respeito do seu efeito na redução das infecções. Deve-se empregálo da maneira mais racional possível, ou seja, aliado a um monitoramento da população do vetor por meio de armadilhas adesivas ou avaliações visuais de ramos por "pragueiros". Por outro lado, a eliminação de plantas doentes (ou roguing) é uma medida fundamental e sua eficácia será maior quanto mais frequentes forem as inspeções.

\section{A necessidade de uma ação urgente e efetiva no controle do HLB no Brasil}

As medidas de controle mencionadas não são suficientes quando adotadas individualmente (Bové, 2006; Gottwald et al., 2007a). Curvas de progresso com base na incidência acumulada de plantas com HLB foram obtidas em quatro propriedades mantidas com e sem controle e também sob influência (ou não) de propriedades vizinhas que não realizam o controle da doença (dados não publicados) (Figura 2). As curvas de progresso são resultantes do ajuste do modelo de Gompertz, feito com base nas proporções acumuladas de plantas erradicadas em 17 pomares de cinco propriedades diferentes em São Paulo, de 2004 a 2008. Mesmo propriedades que fazem um controle rigoroso da doença, com a eliminação sistemática de plantas sintomáticas, podem tornar-se improdutivas e economicamente inviáveis quando sob influência de inóculo externo responsável pelas infecções primárias. Entende-se aqui por inóculo externo propriedades vizinhas, localizadas a menos de $2 \mathrm{~km}$ de distância, que mantêm em seus pomares plantas sintomáticas em grandes quantidades. Nem todos os proprietários de pomares infestados manejam o HLB por meio da eliminação de plantas sintomáticas detectadas em inspeções frequentes. Convencer os produtores que eliminem regularmente plantas sintomáticas é atualmente o maior desafio para o controle efetivo do HLB no Estado de São Paulo. Medidas urgentes deveriam ser adotadas no sentido de eliminar rapidamente os mais de 2 milhões de árvores sintomáticas presentes no Estado.

Considerando a rápida expansão da doença e a inexistência de medidas curativas, é urgente a necessidade de se reduzir o inóculo do HLB (plantas doentes). A influência de pomares e propriedades com alto potencial de inóculo, sobre propriedades nas quais medidas de controle são adotadas, resultam em prejuízos econômicos imediatos, e justifica, portanto, a ação governamental no intuito de eliminar essas fontes de inóculo. O convencimento dos citricultores quanto à necessidade da eliminação rápida de 


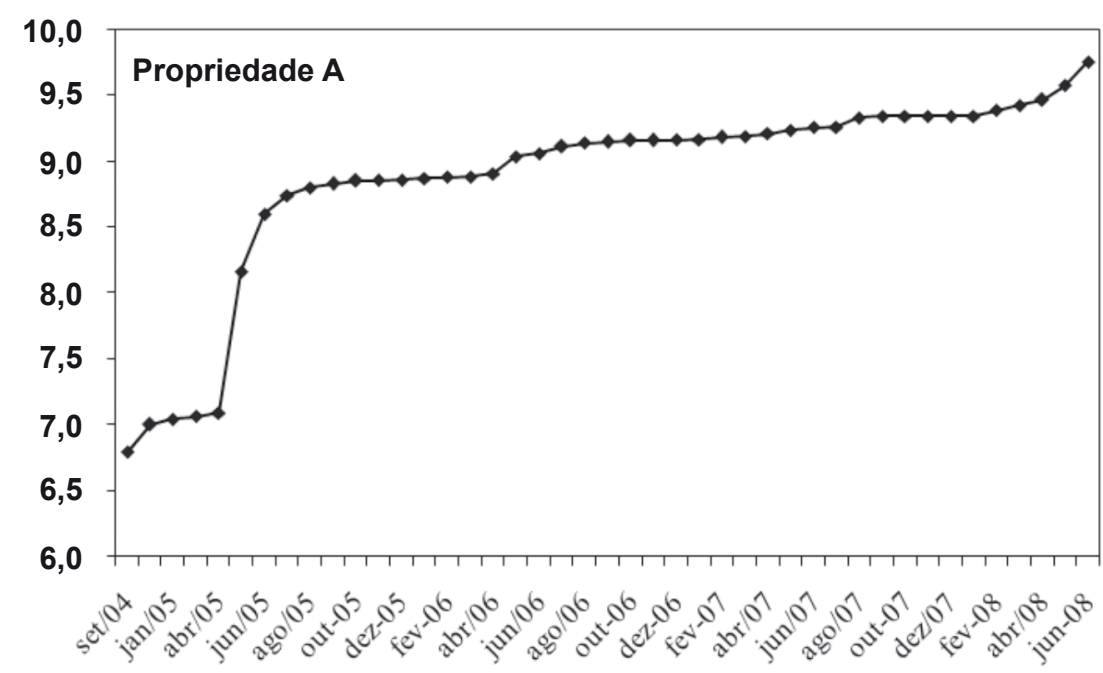

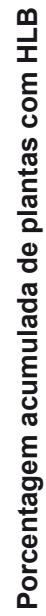

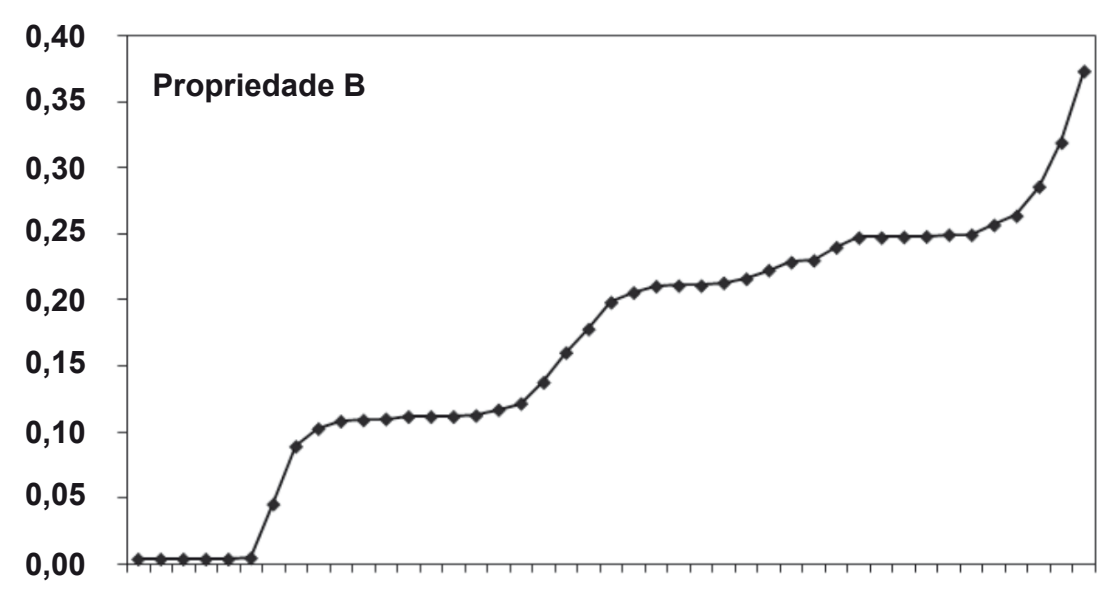

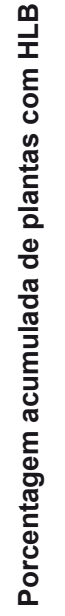

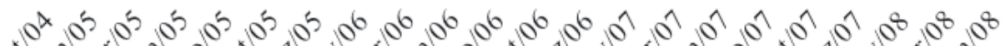

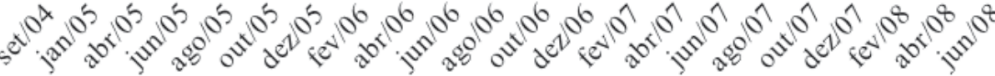

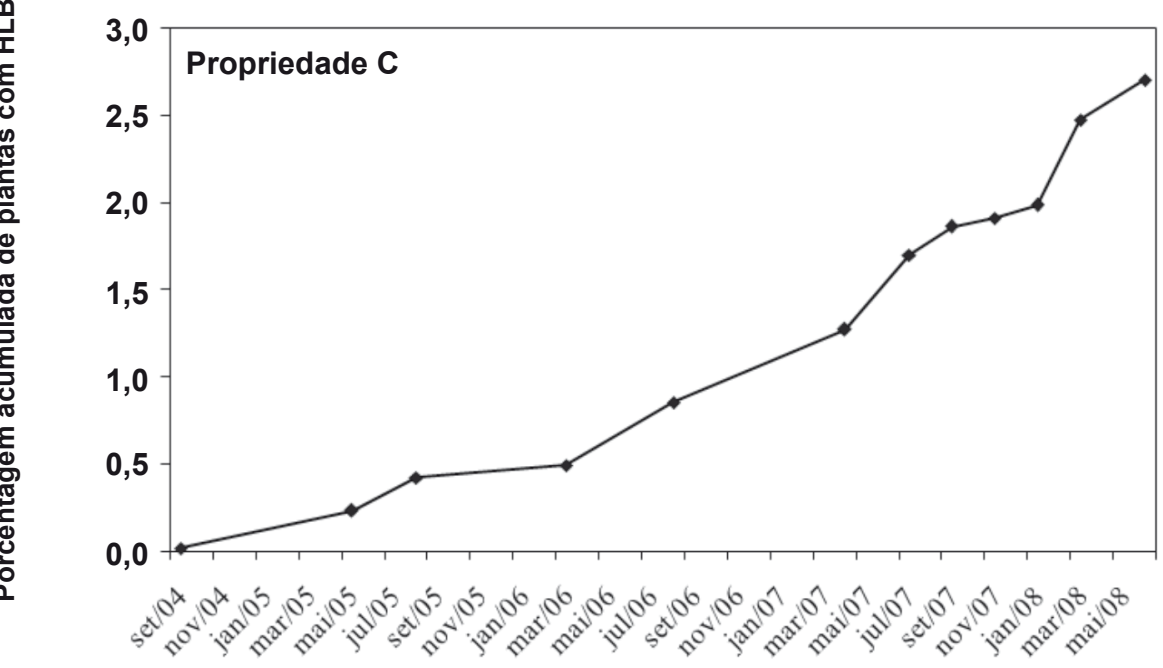

FIGURA 1 - Percentagem de plantas com Huanglongbing erradicadas em propriedades comerciais localizadas na região Centro do Estado de São Paulo, detectadas em inspeções periódicas, de 2004 a 2008. 


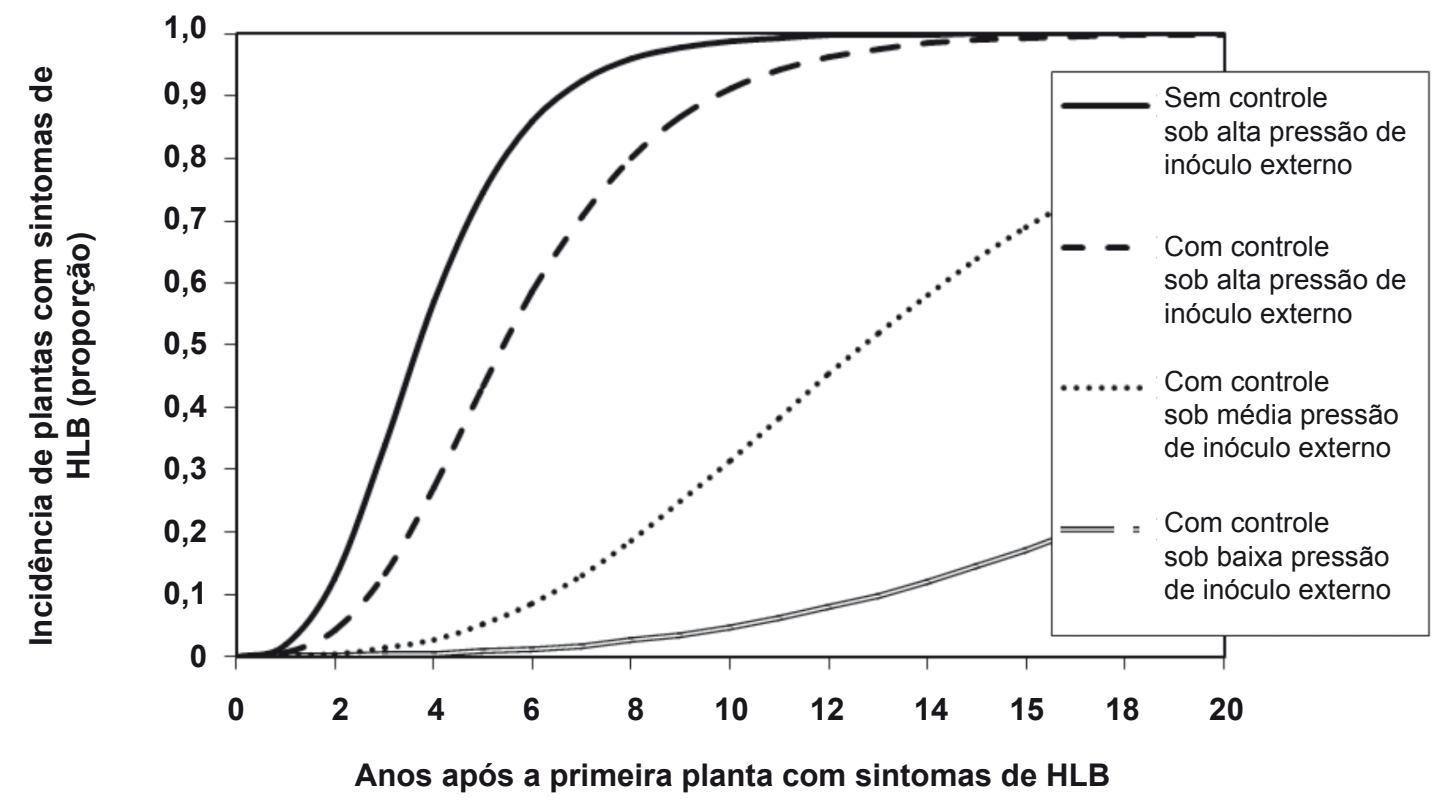

FIGURA 2 - Progresso do Huanglongbing em pomares com e sem controle (erradicação de plantas e controle do vetor), sob a influência ou não de propriedades vizinhas que não realizam o controle da doença (inóculo externo).

plantas sintomáticas é um processo contínuo e de longo prazo. Assim, é muito provável que apenas com uma ação efetiva e conjunta do governo e dos demais integrantes da cadeia citrícola, esse cenário possa ser mudado.

Como apresentado, o HLB é uma doença de difícil manejo. Não são conhecidas medidas de controle curativas e plantas doentes devem ser eliminadas imediatamente após a detecção. Ao mesmo tempo, devem ser realizadas pulverizações periódicas para controle do inseto vetor $(D$. citri), com o intuito de reduzir a probabilidade de ocorrência de novas infecções. Ainda não são conhecidas fontes de resistência ao HLB e todas as espécies e variedades cítricas plantadas no país são suscetíveis a $C a$. Liberibacter. Além das plantas cítricas e do inseto vetor, $\mathrm{Ca}$. Liberibacter tem também como hospedeiro as plantas de $M$. paniculata, largamente distribuídas e plantadas em muitas cidades brasileiras. Há necessidade de inspeções periódicas, no máximo a cada 2 a 4 meses, para detecção e eliminação imediata de plantas com sintomas. Dados experimentais obtidos na comparação de equipes de inspetores, caminhando ao lado das plantas ou em plataformas acopladas a tratores, revelaram a necessidade de várias equipes de inspeção para detecção do maior número possível de plantas sintomáticas em pomares infestados num único momento (Figura 3). O citricultor deve inspecionar seus pomares frequentemente, fazendo uso de inspetores treinados e de preferência em plataformas, que geralmente permitem maior eficiência na detecção de plantas sintomáticas.

Retomando as discussões de Bové (2006) e Gottwald et al. (2007a), pomares com altas incidências da doença devem ser eliminados inteiramente, erradicando-se as plantas com e sem sintomas. Apesar da obrigatoriedade, por lei federal, da eliminação de plantas infectadas, medidas urgentes deveriam ser aplicadas objetivando a eliminação o mais rápido possível de grande parte das plantas infectadas com HLB. Diante disso, propôs-se, em 2008, um novo critério para a eliminação de plantas cítricas em talhões com HLB, considerando a existência de plantas com sintomas da doença, mas não detectadas pelas equipes de inspeção, e outras já infectadas, mas ainda assintomáticas. Na Tabela 2 estão apresentadas as proporções de plantas detectadas por equipes de inspeção caminhando pelo chão, e as estimativas de: a) plantas sintomáticas, considerando uma detecção média de $47,61 \%$ das plantas sintomáticas (Belasque Jr. \& Barbosa, dados não publicados); e b) do total de plantas doentes (infectadas sintomáticas e assintomáticas), considerando que apenas $57,6 \%$ das plantas infectadas, detectadas por PCR em tempo real, apresentam sintomas de HLB, conforme porcentagem média calculada a partir dos dados apresentados por Irey et al. (2006).

Assim, se todas as plantas do talhão estiverem infectadas, de acordo com o trabalho de Irey et al. (2006), ter-se-iam: $100 \%$ x $0,576=57,6 \%$ de plantas com sintomas da doença, e de acordo com o trabalho de Belasque Jr \& Barbosa (dados não publicados), uma equipe de inspeção caminhando pelo chão encontraria: $57,6 \% \times 0,4761=$ $27,42 \%$ de plantas com sintomas da doença. Portanto, adotando-se como limiar para a erradicação de todas as plantas existentes no talhão, a proporção de $28 \%$ de plantas sintomáticas encontradas por uma única equipe 


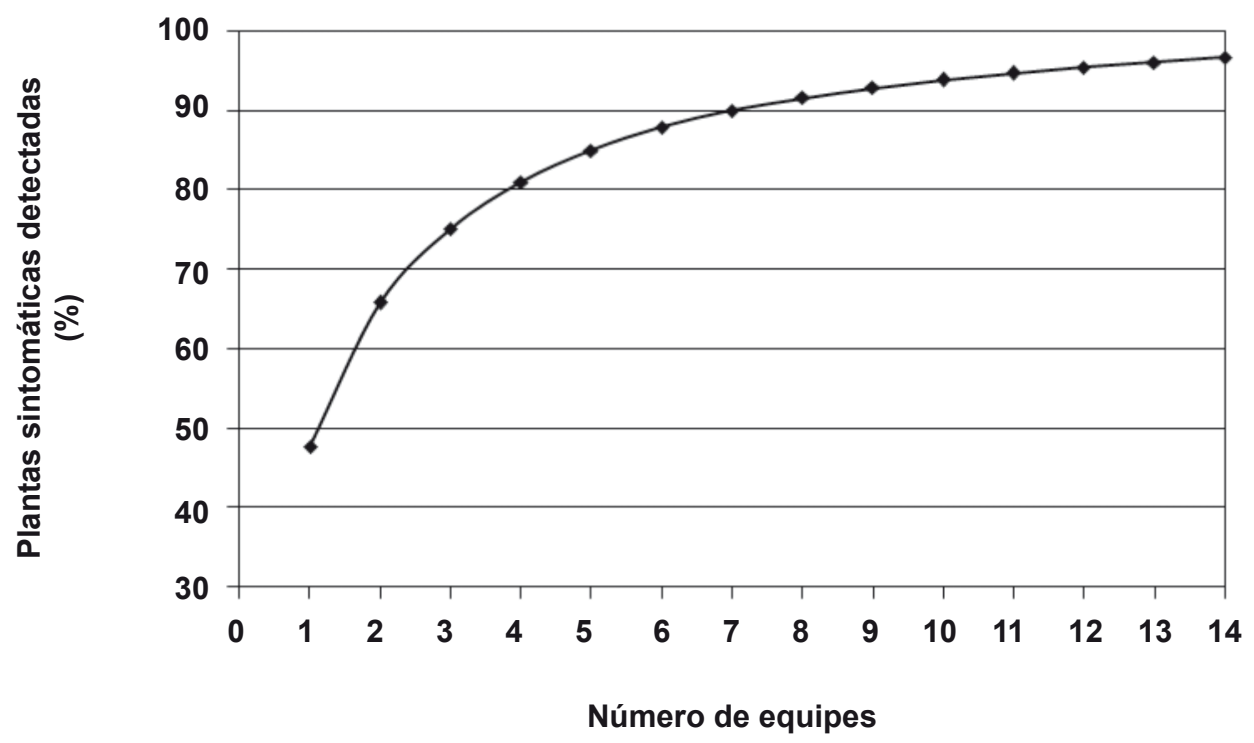

FIGURA 3 - Porcentagem de plantas com HLB, do total de plantas existentes, detectadas em inspeções realizadas por diferentes números de equipes, com inspetores caminhando pelo chão, numa mesma área (Belasque Jr. \& Barbosa, dados não publicados).

de inspetores caminhando pelo chão, teoricamente se estará eliminando talhões com $100 \%$ de plantas infectadas. Ressalta-se que para os cálculos foram considerados valores médios de detecção de plantas em inspeções e também proporções médias de plantas sintomáticas e assintomáticas infectadas. Não há uma regra matemática que determine que sempre ocorram essas proporções. A relação entre plantas detectadas por uma equipe de inspeção e a totalidade de plantas infectadas existentes nos pomares depende de muitos fatores. Parte-se da premissa que as inspeções não detectam todas as plantas sintomáticas, e há outras ainda infectadas assintomáticas. Além disso, o critério proposto considera a proporção de $28 \%$ de plantas detectadas em apenas uma única inspeção, incidência essa extremamente alta para uma doença destrutiva e que deveria ser mantida sob controle por todos os citricultores. Portanto, esse novo critério é conservador, tanto do ponto de vista de controle da doença quanto econômico.

Assumindo a adoção do critério aqui apresentado, compararam-se as incidências de plantas detectadas com HLB por inspeções realizadas em propriedades que controlam a doença, e que estejam localizadas próximas a grandes focos. Foram coletados os dados de inspeções realizadas por citricultores em seis propriedades localizadas na região de Araraquara SP. Nessas seis propriedades foram realizadas, desde 2004, 1225 inspeções rotineiras para detecção de plantas sintomáticas de HLB. Nesse período, os proprietários também realizaram o controle do vetor por meio de pulverizações com inseticidas. Ressalta-se que o controle do HLB em quatro dessas propriedades pode ser considerado razoável, com inspeções a cada 4 a 6 meses, e em apenas duas delas um controle rigoroso da doença, com inspeções mensais ou bimensais. Nas 1225 inspeções realizadas, em $1125(91,8 \%)$ foram encontradas $\leq 5 \%$ de plantas sintomáticas, em $1195(97,6 \%) \leq 10 \%$, em 1216 $(99,3 \%) \leq 15 \%$, e em $1223(99,8 \%) \leq 20 \%$ de plantas sintomáticas. Em apenas duas inspeções $(0,2 \%)$ o número de plantas encontradas superou 20\% (21,6 e $22,6 \%)$.

\section{A Instrução Normativa No. 53}

Em 18 de Março de 2005, um ano após a detecção do HLB em São Paulo, foi promulgada pelo Governo Federal a Instrução Normativa No. 10, posteriormente substituída pela Instrução Normativa No. 32, em 29 de Setembro de 2006, a qual determinou a eliminação de plantas cítricas, e também de $M$. paniculata, quando infectadas por $C a$. Liberibacter. Apesar da existência de legislação federal concernente à erradicação de plantas com HLB, a manutenção das plantas sintomáticas nos talhões infestados permitiu que em Abril de 2008 ao menos 2 milhões de árvores estivessem infectadas no Estado e que aproximadamente $18 \%$ dos talhões tivessem pelo menos uma planta com sintomas do HLB. Portanto, fez-se necessária nova mudança na legislação, e, por essa razão, propôs-se ao Governo federal novo critério para o controle do HLB, aqui descrito e justificado, o qual resultou na Instrução Normativa No. 53 (IN 53), divulgada no Diário Oficial em 17 de Outubro de 2008. 
TABELA 2 - Porcentagens de plantas com sintomas de Huanglongbing detectadas por equipes de inspetores caminhando pelo chão, e respectivas porcentagens estimadas de plantas sintomáticas (detectadas e escapes) e porcentagens de plantas doentes (sintomáticas e assintomáticas)

\begin{tabular}{|c|c|c|}
\hline $\begin{array}{c}\text { Plantas } \\
\text { detectadas (\%) }\end{array}$ & $\begin{array}{c}\text { Plantas } \\
\text { sintomáticas }(\%)^{1}\end{array}$ & $\begin{array}{c}\text { Plantas } \\
\text { infectadas }(\%)^{2}\end{array}$ \\
\hline 1 & 2,1 & 3,6 \\
\hline 2 & 4,2 & 7,3 \\
\hline 3 & 6,3 & 10,9 \\
\hline 4 & 8,4 & 14,6 \\
\hline 5 & 10,5 & 18,2 \\
\hline 6 & 12,6 & 21,9 \\
\hline 7 & 14,7 & 25,5 \\
\hline 8 & 16,8 & 29,2 \\
\hline 9 & 18,9 & 32,8 \\
\hline 10 & 21,0 & 36,5 \\
\hline 11 & 23,1 & 40,1 \\
\hline 12 & 25,2 & 43,8 \\
\hline 13 & 27,3 & 47,4 \\
\hline 14 & 29,4 & 51,1 \\
\hline 15 & 31,5 & 54,7 \\
\hline 16 & 33,6 & 58,3 \\
\hline 17 & 35,7 & 62,0 \\
\hline 18 & 37,8 & 65,6 \\
\hline 19 & 39,9 & 69,3 \\
\hline 20 & 42,0 & 72,9 \\
\hline 21 & 44,1 & 76,6 \\
\hline 22 & 46,2 & 80,2 \\
\hline 23 & 48,3 & 83,9 \\
\hline 24 & 50,4 & 87,5 \\
\hline 25 & 52,5 & 91,2 \\
\hline 26 & 54,6 & 94,8 \\
\hline 27 & 56,7 & 98,5 \\
\hline 28 & 58,8 & $102,1^{3}$ \\
\hline
\end{tabular}

${ }^{1}$ Nos cálculos foi considerada detecção média de $47,61 \%$ do total de plantas sintomáticas existentes no talhão (Belasque Jr. \& Barbosa, dados não publicados).

${ }^{2}$ Considerando que apenas $57,6 \%$ do total de plantas infectadas são sintomáticas, média calculada com os dados apresentados por Irey et al. (2006).

${ }^{3}$ A detecção de $28 \%$ de plantas com sintomas de HLB implica na existência de mais que $100 \%$ de plantas infectadas no talhão.

Diferentemente da IN 32, que determinava a eliminação somente das plantas sintomáticas comprovadamente infectadas, a IN 53 determina a eliminação das plantas sintomáticas e assintomáticas do mesmo talhão quando a incidência da doença é superior a $28 \%$. Além disso, a IN 53 também: a) proíbe a produção de material propagativo de citros, nas áreas de ocorrência do HLB, quando não realizada em ambiente protegido; b) proíbe a produção, comércio e trânsito de plantas de $M$. paniculata nessas mesmas áreas; c) determina que citricultores façam, no mínimo, inspeções trimestrais para detecção de plantas com HLB; e d) determina que sejam feitas amostras compostas, de $10 \%$ das plantas sintomáticas detectadas, para comprovação da infecção por HLB em pomares infestados com a doença.
A implementação da IN 53 permitirá que sejam eliminadas mais rapidamente plantas doentes e pomares inteiros com altas incidências da doença. Embora talvez não inteiramente suficiente para conter o progresso do HLB, somente com essa ação pode-se atualmente pensar em controle efetivo da doença no Brasil. Outro ponto importante é a existência de um limiar que determina a eliminação de todas as plantas dos pomares. Tal limiar exigirá maior atenção dos citricultores com o controle do HLB. Assim, tem-se uma ferramenta que permitirá a eliminação de grandes fontes de inóculo. Além do efeito direto no campo afetado, a eliminação de grandes fontes de inóculo é importante para assegurar aos demais citricultores que realizam o controle em áreas vizinhas, os bons resultados decorrentes desta prática. 


\section{Referências Bibliográficas}

Bassanezi RB, Busato LA, Bergamin Filho A, Amorim L, Gottwald TR (2005) Preliminary spatial pattern analysis of Huanglongbing in São Paulo, Brazil. Proceedings of $16^{\text {th }}$ Conference of International Organization of Citrus Virologists. Riverside CA. pp. 341-355.

Bassanezi RB, Montesino LH, Motta RR (2006b) Effect of inspected sample size on the detection efficiency of blocks with huanglongbing. Proceedings of the Huanglongbing-Greening International Workshop. Ribeirão Preto SP. p. 93.

Bassanezi RB, Montesino LH, Busato LA, Stuchi ES (2006a) Damages caused by huanglongbing on sweet orange yield and quality in São Paulo. Proceedings of the Huanglongbing-Greening International Workshop. Ribeirão Preto SP. p. 39.

Bové JM (2006) Huanglongbing: a destructive, newly-emerging, century-old disease of citrus. Journal of Plant Pathology 88:7-37.

Colleta-Filho HD, Tagon MLPN, Takita MA, De Negri JD, Pompeu Júnior J, Carvalho AS, Machado MA (2004) First report of the causal agent of huanglongbing ("Candidatus Liberibacter asiaticus") in Brazil. Plant Disease 88:1382.

Garnier M, Bové JM, Cronje CPR, Sanders GM, Korsten L, Le Roux HF (2000) Presence of "Candidatus Liberibacter africanus" in the Western Cape province of South Africa. Proceedings of $14^{\text {th }}$ Conference of International Organization of Citrus Virologists. Riverside CA. pp. 369-372.

Gottwald TR, Aubert B, Huang KL (1991) Spatial pattern analysis of citrus greening in Shantou, China. Proceedings of $11^{\text {th }}$ Conference of International Organization of Citrus Virologists Riverside CA. pp. 421-427.

Gottwald TR, Aubert B, Zhao XY (1989) Preliminary analysis of citrus greening (Huanglongbing) epidemics in the People's Republic of China and French Reunion Island. Phytopathology 79:687-693.

Gottwald TR, da Graça JV, Bassanezi RB (2007a) Citrus huanglongbing: the pathogen and its impact. Plant Health Progress 6 September 2007. Online (doi: 10.1094/PHP-2007-0906-01$\mathrm{RV})$.

Gottwald TR, Irey M, Gast T, Parnell S, Taylor E, Hilf ME (2007b) Spatio-temporal analysis of an HLB epidemic in Florida and implications for future spread. Proceedings of $17^{\text {th }}$ Conference of International Organization of Citrus Virologists. Riverside CA.
Halbert SE (2005) The discovery of huanglongbing in Florida. Proceedings $2^{\text {nd }}$ International Citrus Canker and Huanglongbing Research Workshop, Orlando FL. p.50. H-3.

Irey MS, Gast T, Gottwald TR (2006) Comparison of visual assessment and polymerase chain reaction assay testing to estimate the incidence of the Huanglongbing pathogen in commercial Florida citrus. Proceedings of Florida State Horticultural Society 119:89-93.

Jagoueix S, Bové JM, Garnier M (1994) The phloem-limited bacterium of greening disease of citrus is a member of the $\alpha$ subdivision of the Proteobacteria. International Journal of Systematic Bacteriology 44:397-386.

Lopes SA, Frare GF, Yamamoto PT, Ayres AJ, Barbosa JC (2007) Ineffectiveness of pruning to control citrus huanglongbing caused by Candidatus Liberibacter americanus. European Journal of Plant Pathology 119:463-468.

Manjunath KL, Halbert SE, Ramadugu C, Webb S, Lee RF (2008) Detection of 'Canditatus Liberibacter asiaticus' in Diaphorina citri and its importance in the management of citrus huanglongbing in Florida. Phytopathology 98:387-396.

Martínez Y, Llauger R, Batista L, Luis M, Iglesia A, Collazo C, Peña I, Casín JC, Cueto J, Tablada LM (2009) First report of 'Candidatus Liberibacter asiaticus' associated with Huanglongbing in Cuba. Plant Pathology 58:389-389.

Neves MF, Lopes FF, Trombin VG, Amaro AA Neves EM, Jank MS (2007) Caminhos para a Citricultura: uma agenda para manter a liderança mundial. São Paulo SP. Editora Atlas SA.

Roistacher CN (1996) The economics of living with citrus diseases: huanglongbing (greening) in Thailand. Proceedings of $13^{\text {th }}$ Conference of International Organization of Citrus Virologists Riverside CA. pp. 279-285.

Tatineni S, Sagaram US, Gowda S, Robertson CJ, Dawson WO, Iwanani T, Wang N (2008) In planta distribution of 'Canditatus Liberibacter asiaticus' as revealed by polymerase chain reaction (PCR) and real-time PCR. Phytopathology 98:592-599.

Teixeira DC, Danet JL, Eveillard S, Martins EC, Jesus Junior WC, Yamamoto PT, Lopes AS, Bassanezi RB, Ayres AJ, Saillard C, Bové JM (2005) Citrus hanglongbing in São Paulo State, Brazil: PCR detection of the 'Candidatus' Liberibacter species associated with the disease. Molecular and Cellular Probes 19:173-179.

Tersi FA (2008) Experiências no manejo do Huanglongbing (HLB) - Greening no Brasil. Jaboticabal SP. 